\title{
The Use of Radio Telemetry as an Aid in the Retrieval of Bowhead Whales (Balaena Mysticetus) Struck during the Annual Eskimo Subsistence Hunt in Alaska
}

\author{
ERICH H. FOLLMANN ${ }^{1}$ and ARTHUR E. MANNING ${ }^{1,2}$
}

(Received 14 June 1988; accepted in revised form 5 December 1988)

\begin{abstract}
Over past years the number of bowhead whales struck and lost during the annual subsistence hunt by Eskimos in northern Alaska has averaged about $50 \%$. This is a significant number of lost animals, especially for a species considered to be rare and endangered, and steps must be taken to reduce this loss. A project was initiated in 1983 to determine the feasibility of using radio telemetry to aid in the recovery of bowhead whales struck during the subsistence hunt. The radio transmitter was placed in the whaling float to minimize the problem of signal attenuation by marine waters. The stainless steel attachment plates worked flawlessly to stabilize the radio transmitter inside the float and to seal the hole cut in the float to insert the radio transmitter. With directional receiving antennas and receivers, floats could be detected at several kilometres from boats and at over $40 \mathrm{~km}$ from aircraft. Fifteen whaling crews were instrumented for the fall subsistence hunts beginning in 1983 at Kaktovik and in 1986 at Nuiqsut. Eight of 12 whales struck were retrieved during the course of this study, 2 of the 8 because they were found by virtue of the radio signals transmitted from the floats 11 and $48 \mathrm{~km}$ offshore. Floats attached to the 4 whales that were lost during this period were radio-located but the harpoons had pulled out of 2 of these whales. The other two floats were not attached to whales when found and the distances from shore were too far to safely retrieve the equipment to determine the exact reason for loss. A $67 \%$ retrieval rate was achieved during this study, up from $50 \%$ had radio telemetry not been used. Radio telemetry has proven to be a successful technique to support the subsistence hunt for the bowhead whale, and the Alaska Eskimo Whaling Commission is currently expanding its use to other villages where relatively ice-free waters are conducive to its use.
\end{abstract}

Key words: bowhead whale, Balaena mysticetus, Eskimo subsistence hunt, Alaska, radio telemetry

RÉSUMÉ. Au cours des dernières années, le taux de baleines franches touchées et perdues durant la chasse annuelle de subsistance menée par les Eskimos du nord de l'Alaska, s'est situé en moyenne aux environs de 50\%. Cela représente un nombre important d'animaux perdus, surtout pour une espèce que l'on considère comme rare et en voie d'extinction, et des mesures doivent être prises pour réduire cette perte. Un projet a été lancé en 1983 pour déterminer s'il est faisable d'utiliser la radio-télémétrie pour aider à récupérer les baleines franches touchées durant la chasse de subsistance. Le radio-émetteur était placé dans le flotteur attaché à la baleine, pour minimiser le problème de l'atténuation du signal par les eaux marines. les plaques de raccordement en acier inoxydable ont fonctionné sans aucun problème pour stabiliser le radioémetteur à l'intérieur du flotteur et pour sceller l'orifice pratiqué dans le flotteur pour l'insertion du radio-émetteur. Avec des antennes directives de réception et des récepteurs, on a pu détecter les flotteurs à plusieurs kilomètres à partir des bateaux et à plus de $40 \mathrm{~km}$ à partir d'appareils áriens. Quinze équipes de chasseurs de baleines ont reçu des appareils pour les chasses de subsistance de l'automne qui ont commencé en 1983 à Kaktovik et en 1986 à Nuiqsut. Huit des 12 baleines touchées ont été retrouvées au cours de cette étude, 2 des 8 grâce aux signaux de radio transmis à partir des flotteurs à 11 et à $48 \mathrm{~km}$ du rivage. Les flotteurs reliés aux 4 baleines qui ont été perdues au cours de cette période ont été retrouvés par radio mais les harpons étaient sortis de 2 de ces baleines. Les deux autres flotteurs n'étaient pas reliés aux baleines au moment où on les a retrouvés et les distances du rivage étaient trop grandes pour permettre la récupération sécuritaire de l'équipement en vue de déterminer la cause exacte de la perte. Un taux de récupération de $67 \%$ a été atteint durant cette étude, soit une hausse de $50 \%$ par rapport à la non utilisation de la radio-télémétrie. Cette dernière a montré qu'elle était une technique efficace pour soutenir la chasse de subsistance à la baleine franche, et la Alaska Eskimo Whaling Commission est actuellement en train d'étendre son usage à d'autres villages où des eaux relativement libres de glace sont propices à son utilisation.

Mots clés: baleine franche, Balaena mysticetus, chasse de subsistance des Eskimos, Alaska, radio-télémétrie

Traduit pour le journal par Nésida Loyer.

\section{INTRODUCTION}

From 1968 through 1983 it is estimated that 378 bowhead whales (Balaena mysticetus) were harvested, while an additional 311 were struck and lost (Dronenburg et al., 1983; Murphy and Jarrell, 1983; Alaska Eskimo Whaling Commission [AEWC], unpubl. data); older records can be found in Marquette and Bockstoce (1980). A 45\% loss of struck whales is significant and is a problem of concern to the whaling communities and to the International Whaling Commission (IWC) (Mitchell and Reeves, 1980). The IWC (1982) and others (Mitchell and Reeves, 1980) recommended that the subsistence hunt end in light of the rare and endangered status of the whale. The population estimate of below 2000 animals in the mid-1970s (IWC, 1978) is currently 7800 (Zeh and Raftery, in press), a number that continues to allow the subsistence hunt under an annual quota system. Given that the hunt continues, it is essential to reduce the numbers of struck and lost whales, thus improving the harvest and meeting the dietary needs of the peoples traditionally dependent on this food source.

During the subsistence hunt for the bowhead whale in northern Alaska, it is inevitable that some of the animals struck with bombs and harpoons are not recovered and are thereby regarded as struck but lost. The inability to recover some struck whales results from environmental factors such as extensive ice cover, which prevents pursuit with boats or provides shelter to the whales. For example, from 1982 through 1987, 18 struck whales were thought to have had sought shelter under ice during the spring hunts (AEWC, unpubl. data), thus constituting a significant number of lost whales. Another factor that can lead to the loss of a whale, although less common, is a storm that forces whaling crews to cut loose a whale being towed to shore so that the small craft can seek shelter until the storm abates.

Technical problems have also led to the loss of whales. For example, a bomb that fails to explode (Rainey, 1940; Mitchell and Reeves, 1980; Dronenburg et al., 1983) greatly reduces

\footnotetext{
${ }^{1}$ Institute of Arctic Biology, University of Alaska Fairbanks, Fairbanks, Alaska 99775-0180, U.S.A.

${ }^{2}$ Present address: Geophysical Institute, University of Alaska Fairbanks, Fairbanks, Alaska 99775-0800, U.S.A.

(C) The Arctic Institute of North America
} 
the probability of inflicting a mortal wound. A bomb as referenced here is an explosive device that penetrates the whale and detonates after a slight delay. It is usually projected with a darting gun (George, 1981; Mitchell et al., 1986) attached to the end of a wooden shaft, the entire unit being thrown by hand. Also attached to the shaft is a harpoon to which a line and float are fastened. The harpoon head penetrates the whale immediately before the bomb, and when the shaft and darting gun are withdrawn the harpoon, with line and float, remains attached to the whale. When a shoulder gun is used to fire a bomb, a harpoon with float is attached immediately before the bomb, so that the struck whale is suitably marked. The attachment of a float before the bomb is a requirement established in the management guidelines of the AEWC.

The AEWC is currently supporting four projects to reduce the loss of struck whales: 1) the development of a more effective bomb to kill whales; 2 ) the distribution to whaling crews of harpoons that have more holding capability; 3 ) evaluation of an underwater acoustic "pinger" and receiving equipment to aid in the recovery of whales in ice-covered waters; and 4) an expanded use of radio-instrumented whaling floats to aid in the recovery of struck whales in relatively ice-free waters. The latter is the subject of this report.

\section{Project Approach}

The approach taken in this project was to apply an existing technology, radio telemetry, to the equipment already in use by Inupiat whalers. Traditionally, floats have been used on harpoon lines to mark struck whales (Mitchell et al., 1986). The floats in use now are large, inflatable spheres made of synthetic materials that remain surfaced except when whales are in a deep dive. The brightly colored floats provide a clue to the presence of a whale. If a whale has been lost for even more than a few hours, the problem of relocating it can be quite severe, even in open-water conditions. The difficulty is significantly compounded when the seas are rough or when covered with broken ice. Under such conditions efforts to find a float, and thus the whale, often end in failure, even when aircraft are used.

By attaching radio transmitters to the whaling equipment, the search range is greatly extended, thus significantly increasing the probability of maintaining contact with or finding a struck whale. The radio signal increases the range of contact with a struck whale, even when the whale or float is not in visual range.

Once a whale is struck, the only equipment attached to it is a harpoon, a $61 \mathrm{~m}$ line, and a brightly colored float. Thus a radio-transmitter attachment would be limited to one of these devices. Because radio signals are greatly attenuated by salt water (or any water of high conductivity), the only plausible location for a radio transmitter is the float, because it rides at the surface unless the whale is in a deep dive or is swimming fast enough to drag it beneath the surface as it is being towed. Most often, however, the float is at the surface, where a signal is detectable. Thus, whaling crews equipped with radio receivers and directional receiving antennas can precisely locate the float, and hence the attached whale, from a whaling boat or an aircraft.

Because of the limitations imposed by marine waters on the use of radio telemetry, it was evident from the start that any such development and testing would have to be conducted in areas of relatively ice-free water. A float under the ice in most cases could not be detected. This generally restricts the application of this technique to the fall whaling villages of Barrow, Kaktovik, and Nuiqsut, although relatively open water also prevails in spring at the villages of Gambell and Savoonga on St. Lawrence Island and, at times, at Barrow (Fig. 1). The initial work began at Kaktovik in 1983 and was subsequently expanded to Nuiqsut in 1986 . This effort is synthesized below, but further details can be found in Follmann $(1986,1987)$ and in Follmann and Manning $(1984,1985)$. The principal objective was to determine the feasibility of using radio telemetry to increase the recovery of struck whales.



FIG. 1. North Slope Borough, showing the villages of Kaktovik and Nuiqsut, where radio-instrumented whaling floats were tested and used by whaling crews, 1983-88.

\section{MATERIALS AND METHODS}

\section{Equipment Selection}

Radio transmitter: The radio transmitter selected for this project was a Model 6A manufactured by Telonics ( $932 \mathrm{E}$. Impala Avenue, Mesa, Arizona 85204, U.S.A.) operating in the range of $148-149 \mathrm{mHz}$. It consists of a hermetically sealed, rectangular metal box containing the transmitter and lithium batteries with an external $1 / 4$ wavelength $(46 \mathrm{~cm})$ vertical whip antenna (Fig. 2); the entire package weighs about 550 g. The $34 \mathrm{msec}$ pulse width of the transmitted signal is longer than that usually used for radio tracking, but it facilitates hearing a weak signal by those inexperienced in radio tracking. The transmitters are equipped with an internal reed switch with which the transmitter can be turned off when in storage using an externally placed magnet (Fig. 3). The theoretical life span is $15-30$ months, depending on the pulse rate of the individual radio transmitters. The shelf life of these units is equal to that of the lithium batteries, thus about 8-10 years should the transmitter never be activated.

Early in the project a decision was made to place the radio transmitter inside the float instead of on its outer surface. The outer attachment was considered unsuitable because: 1) potential damage to the unit could occur from ice floes present during the fall whaling season; 2) signal attenuation 


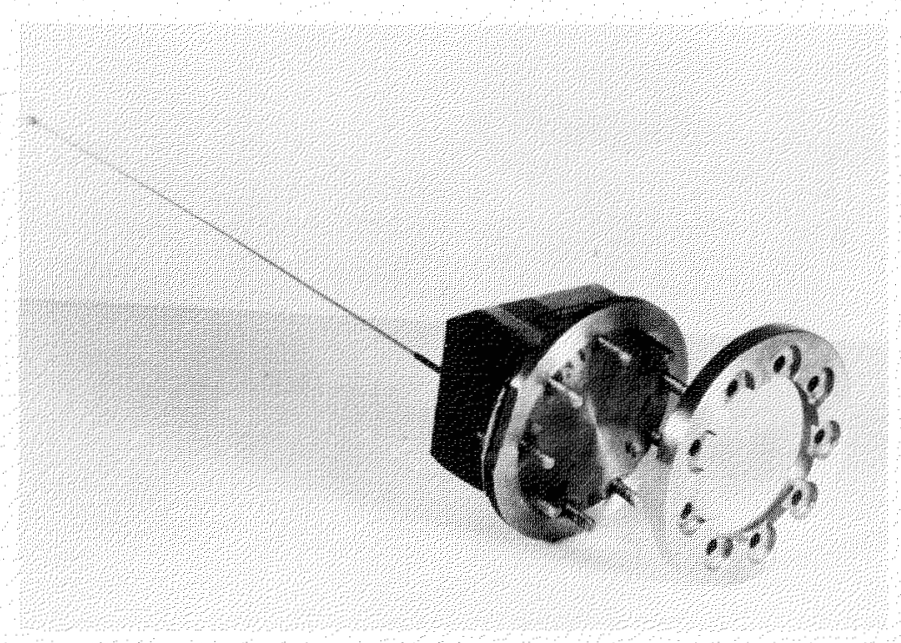

FIG. 2. Radio transmitter and stainless steel plates ready to be attached to a whaling float.

by the salt water would occur should the antenna be wet as when in tow by a whale; 3 ) an externally attached unit would be subject to damage in the whaling boat and when the 61 $m$ long rope was rapidly unwinding off the surface of the float after being attached to a whale; and 4) a person could be injured falling on the unit if it were located on the surface. Although an internally placed radio transmitter eliminated those problems, the key problem with that approach was maintaining the buoyancy of the float, since a hole had to be cut in its wall to insert the radio transmitter.

Attachment Device: To place a radio transmitter inside a float a device was designed to serve two functions: to fasten the radio transmitter firmly inside the float, and to seal the hole cut in the wall of the float. This is accomplished by using two circular steel plates, one a solid disk to which the radio transmitter is attached and the other with the center removed (Figs. 2 and 3). Both are machined from No. 304 stainless steel to the specifications noted in Fig. 3. The outer surface of the solid plate and the inner surface of the flat ring have shallow grooves machined in them where they make contact with the float wall. These grip the float material when the two places are bolted together.

Nine $6.4 \mathrm{~mm}$ diameter stainless steel flathead bolts are used to fasten the plates together. The heads of the bolts are countersunk and silver-soldered into the inner surface of the flat disk so that the shafts of the bolts protrude through the plate, through the hole cut in the float, and then through holes drilled through the outer flat ring (Figs. 2 and 3). Stainless steel locknuts, when tightened, draw the plates together and simultaneously squeeze the float material between them, thus firmly sealing the hole cut in the float. A later improvement involves cutting a smaller hole $(6 \mathrm{~cm}$ diameter) in the float to insert the radio transmitter and plate to which it is attached. Around this hole nine $6.4 \mathrm{~mm}$ holes are cut in the float material through which the bolt studs fit. Thus when the plates are squeezed together both the grooves machined into



FIG. 3. Specification of the stainless steel device used to attach the radio transmitter to the inside of a whaling float and of the radio transmitter. All dimensions are in inches. 
the plates facing the float wall and that portion of the float wall within the circumference of the nine studs prevent slippage of the float wall from between the plates when the float is subsequently inflated. The net result of both approaches is a non-corrosive device that both seals the float, thereby maintaining buoyancy, and stabilizes the radio transmitter inside it.

The magnetically sensitive reed switch for turning the radio transmitter on and off as needed is located inside the transmitter in such a position that the externally attached magnet can be used to activate it. A stainless steel clip is held in place by one of the nine bolts on the plate (Fig. 3). The magnet pushed under the clip is firmly held in place over the reed switch. To activate the transmitter it is necessary merely to remove the magnet. A 1-2 m lanyard with one end attached to the magnet and the other to a gunwhale, cleat, or other part of the boat (Figs. 4 and 5), or even to the tow rope, ensures that the radio transmitter is activated when the float is thrown overboard upon striking a whale.

Radio Receiver and Antenna: Two radio receivers were used on this project. The first was the Model TR-1 receiver manufactured by Telonics, but its discontinuation by the manufacturer required the selection of another as the project expanded. The receiver chosen was the Model TRX1000S manufactured by Wildlife Materials, Inc. (Route 1, Carbondale, Illinois 62901 , U.S.A.). Both are physically small in size and light in weight, distinct advantages because they reduce the storage space requirements on board the whaling boats. The TR-1 has 10 crystal-controlled channels, while the TRX1000S can be tuned continuously over $1 \mathrm{mHz}$. Both have internal nickel-cadmium batteries, which can be recharged or operated from both DC and AC power sources. Although both have external speakers, headphones are used by whaling crews to improve reception.

The receiving antenna was a Model RA-2AK H-antenna supplied by Telonics. It is small in size $(26.7 \times 100 \mathrm{~cm}$, with a $30.5 \mathrm{~cm}$ wooden handle), efficient ( $4 \mathrm{dBd}$ gain), highly directional, and easy to use. In addition, it easily disassembles into six components that are stowed in a vinyl case, thus



FIG. 4. Radio-instrumented whaling float with harpoon line wrapped around the outer attachment plate. Magnet switch and lanyard attached to the boat visible in lower half of photo.

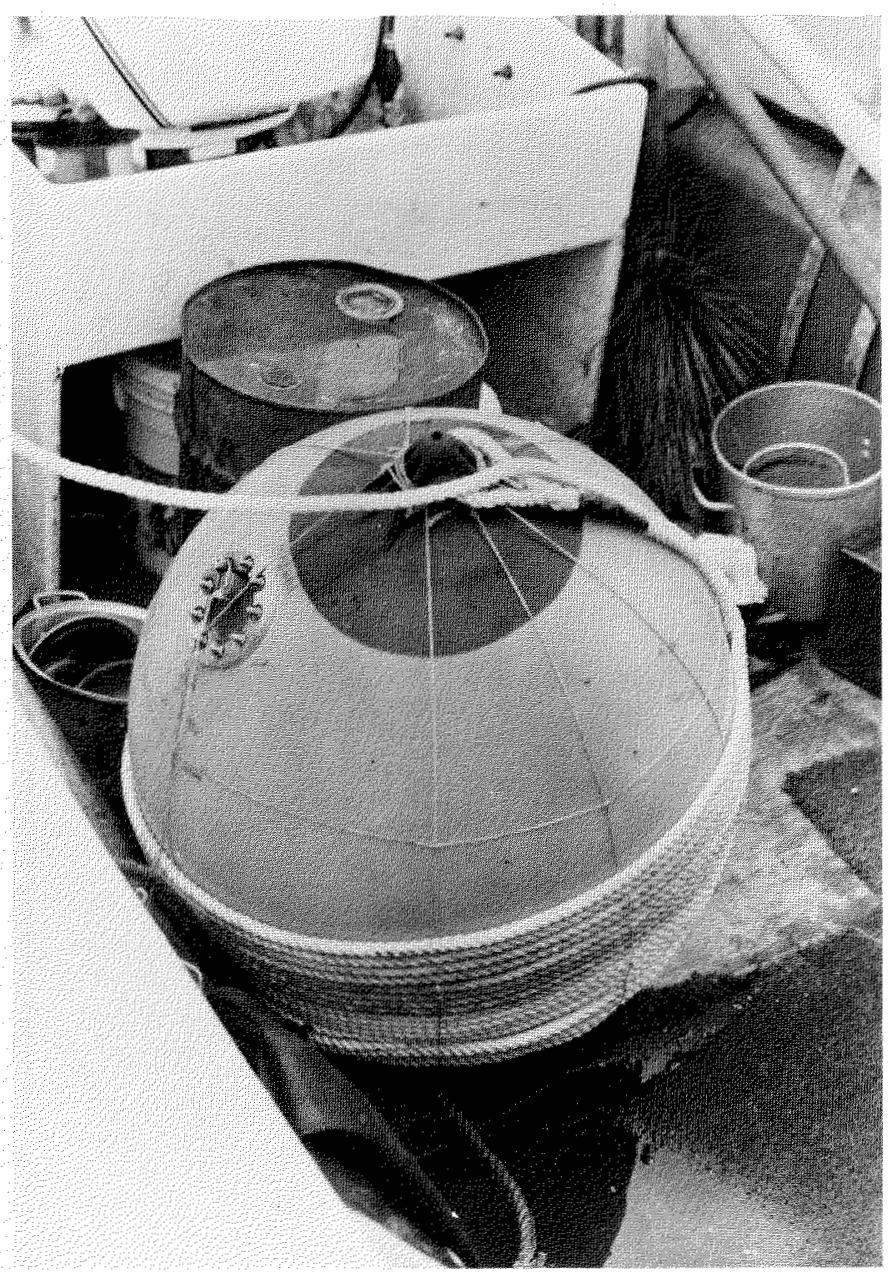

FIG. 5. Radio-instrumented whaling float with harpoon rope wrapped around the lower half of the float, thereby avoiding contact with the outer attachment plate. Magnet switch is in place and lanyard extends downward where it is attached to the boat.

greatly reducing storage space requirements. While it is most often held by hand when tracking from a boat or the ice edge, it is also easily attached to an aircraft, especially those with a wing strut.

Floats: The float selected for this project is identical to those in use by Eskimo whalers. They are Model A-4 Polyform Buoys that have a maximum operating circumference of $190 \mathrm{~cm}$ and are colored fluorescent red. They are attached to a $61 \mathrm{~m}$ long rope that has the harpoon attached to the other end. Upon striking a whale with the harpoon, the float is thrown overboard and the rope, which is wrapped around the float (Figs. 4 and 5), unwinds should the whale swim away.

\section{Field Tests}

The tracking range of the internally mounted radio transmitter was tested with floats on both fresh and marine water. Due to the line-of-sight characteristics of the $148 \mathrm{mHz}$ frequency range selected for this project, it was necessary to determine whether the range of detection from aircraft approached theoretical ranges.

Conducting range tests from aircraft does not imply that the authors consider aircraft indispensable to this program 
or that they will always be needed to track struck whales or to find lost ones. The primary tracking method involves the whaling boats, and in most cases the boats are able to maintain radio contact, as well as visual contact in many cases, with a fleeing whale. However, there are situations in which pursuit is hindered by ice, rough seas, and darkness, and on occasion dead whales being towed to shore must be cut loose because of storms or approaching ice that imperil the boats. In these situations a whale may have been lost for several days, and aircraft are the only efficient means to search, whether it involves search over water in a twin-engine aircraft to precisely locate the float or flying along the shore in a single-engine aircraft to establish a compass bearing so that boats can be directed to the float. Aircraft, therefore, are considered to be an important backup to the use of radioinstrumented floats for retrieving struck whales. The fall whaling villages of Kaktovik, Nuiqsut, and Barrow have small aircraft available either at the village or at Prudhoe Bay, which is centrally located along the arctic coast. To date, the whaling communities have been willing to risk aircraft costs to increase the probability of finding a struck but lost whale.

The test over freshwater using aircraft entailed placing the radio-instrumented float on a freshwater pond in interior Alaska. A test over marine water was conducted at Barrow, with a float anchored near shore. Additional information on range was obtained when in search of floats that had been attached to whales near Kaktovik.

The technique used to range test the radio transmitters from an aircraft entailed attaching an $\mathrm{H}$-antenna to the strut of a Cessna aircraft, with the antenna pointed outward toward the wing tip. Tests were conducted by selecting an altitude of at least $600 \mathrm{~m}$ and flying the aircraft in one direction away from the float. At $8-32 \mathrm{~km}$ intervals the aircraft was tightly circled to maximize signal reception when the wing tip was pointed toward the float. This procedure continued until the transmission was no longer detectable. The altitude was then increased by up to $300 \mathrm{~m}$ or until the signal was again detectable, and then the entire procedure was repeated until the signal could no longer be detected.

Range tests from boats were not conducted by the authors because of logistical, time, and environmental constraints. The boats used for fall whaling are also used for subsistence fishing and hunting and for transport. Given the limited openwater season during which these activities must take place, and the late summer-early fall time during which fairly frequent storms and periodically encroaching ice further restrict boat use, it was felt best not to interfere with these activities by requesting the use of a boat for range tests. Also, Kaktovik and Nuiqsut are remote from areas where other similar boats could be obtained to conduct the tests. Unlike the spring hunt, where traditional skin boats (umiaqs) or equivalent boats are used, the boats used in the fall hunt range from open skiffs to enclosed boats with varying cabin heights. Given the line-of-sight characteristics of the $148 \mathrm{mHz}$ frequency range, the maximum range would depend on the height of the receiving antenna. Thus, a cabin cruiser would achieve a greater range of reception than an open skiff. Since the theoretical range of the radio-instrumented floats is less than $6 \mathrm{~km}$ for a "typical" boat, determining an exact range was not considered critical. Maximum range is certainly much greater than the visual range of detection, particularly in rough seas or when the ice floes are present. Radio tracking information was collected, however, from whalers after striking whales.

\section{Equipment Provision to Whaling Crews}

After concluding that the above equipment was suitable for further testing during the fall subsistence hunt, whalers at the villages of Kaktovik in 1983 and Nuiqsut in 1986 were provided with this instrumentation. To simplify the use of the equipment, the radio transmitters in the floats of all whalers in each village were set for radio frequencies of $148.700 \mathrm{mHz}$ in Kaktovik and $148.900 \mathrm{mHz}$ in Nuiqsut. Thus, all radio receivers in one village were tuned to the same radio frequency. Yet the receivers were capable of being tuned to the radio frequency of the other village should assistance or sharing of equipment between villages be desirable.

Even though whalers within one village often hunt together, it is possible that two or more whales could be struck simultaneously or be lost, thus resulting in more than one radio transmitter being activated at one time. To be able to differentiate between the floats, each transmitter was designed to operate at a different pulse rate, in the range of 75-148 pulses per minute at Kaktovik and 70-136 pulses per minute at Nuiqsut (Table 1). This permitted identification of a whale should it become lost and later be found. The pulse rate of the radio transmitter would identify the whaling crew that struck the whale. The four radio transmitters at Kaktovik with pulse rates of 75 per minute (Table 1) are the first several floats that were given to Kaktovik whalers in 1983, before this refinement in the identification system was initiated. When these units are refurbished after 4-5 years of use, their pulse rates will be changed so that each is unique.

Each whaling crew was given a radio-instrumented float, a radio receiver, a receiving antenna, headphones, $\mathrm{AC}$ and $D C$ receiver charging units, and instructions on the proper use and care of the equipment. All tracking was done by the whaling crews, except on several occasions in the fall of 1983 and 1984 when the authors were requested to assist in aerial searches for struck and lost whales.

\section{RESULTS AND DISCUSSION}

\section{Equipment Performance}

Radio Transmitter and Float Attachment Plates: The radio transmitters performed flawlessly under the environmental

TABLE 1. The pulse rates of radio-instrumented whaling floats provided to whaling crews at the villages of Kaktovik and Nuiqsut, Alaska, 1983-88

\begin{tabular}{|c|c|c|c|}
\hline \multicolumn{2}{|c|}{ Kaktovik $(148.700 \mathrm{mHz})$} & \multicolumn{2}{|c|}{ Nuiqsut $(148.900 \mathrm{mHz})$} \\
\hline Whaling captain & $\begin{array}{l}\text { Pulse rate } \\
\text { per minute }\end{array}$ & Whaling captain & $\begin{array}{l}\text { Pulse rate } \\
\text { per minute }\end{array}$ \\
\hline$\overline{\text { Tom Agiak }}$ & 96 & Thomas Napageak & 70 \\
\hline Herman Aishanna & 75 & Edward Nukapigak, Jr. & 89 \\
\hline Daniel Akootchook & 120 & Billy Oyagak & 136 \\
\hline Isaac Akootchook & 108 & Sam Taalak & 87 \\
\hline Archie Brower & 75 & Patsy Tukle & 108 \\
\hline Tommy O. Gordon & 84 & & \\
\hline Joseph Kaleak & 148 & & \\
\hline Alfred Linn & 75 & & \\
\hline Nolan Solomon & 75 & & \\
\hline Jimmy Soplu & 104 & & \\
\hline
\end{tabular}


conditions encountered during the fall hunt in northern Alaska. This season is not characterized by extremely cold weather; thus battery failure is not a problem. The lithium battery used to power this radio transmitter has had a long history of success at ambient temperatures of $-40^{\circ} \mathrm{C}$ and lower on a variety of animals radio-tagged in northern Alaska.

The attachment plate design met both requirements that guided its development. Radio transmitters in all cases were firmly held in place inside the floats, and the seal developed by squeezing the float material between the inner and outer steel plates was excellent. No floats were ever known to have sunk or shown to be weakened by the location of the plates. One float attached to a whale in 1988 near Kaktovik was dragged through and under heavy ice, which tore a gash in the float near the plate. The float was partially deflated and filled with water, but the plate and radio transmitter were undamaged and still producing a signal. Details of this strike and recovery are described in a subsequent section.

Nine different floats were attached to whales a total of 13 times. Four of these floats were lost, two because they were too far offshore to retrieve safely $(120$ and $45 \mathrm{~km})$ and two because they could not be radio-located. One of the floats that was not radio-located was attached to a whale in 1983 along with another containing a radio transmitter, and both were transmitting on the day of attachment. One of the floats was radio-located four days later $120 \mathrm{~km}$ northwest of Kaktovik, but a signal from the other was not detected. The presence of extensive ice floes in the entire region of the Beaufort Sea that fall suggests that the float may have been either under a floe, from which location a radio signal would not be detectable, or damaged and sunk as a result of being torn on a floe while in tow by the whale.

The other float that was not radio-located or retrieved after deployment, although it was transmitting when attached to the whale, was tied by a rope to an instrumented float already attached to a whale. This whale, struck in 1988, dragged both floats through and under heavy ice, and after one such submersion under an ice floe only the first float attached to the whale surfaced. The other was apparently sheared off by the ice. Since radio signals are attenuated by salt water, the fate of this float is unknown. Perhaps the knot used to hurriedly tie the float onto the harpoon line gave way under subsequent stress.

The floats retrieved proved to be durable during six years of service. Of the five floats attached to whales and retrieved, one was attached to a whale in 1984 and again in 1986, and a second float was attached to struck whales in 1984, 1986, 1987 , and 1988. Ensuring that the nuts were tight on the attachment plates was all that was necessary during this time, thus attesting to the durability and success of the radiotransmitter attachment device designed for this application.

The only change over the six-year evaluation program was the redesign of the clip holding the magnet in place. The less secure clip used in the early design sometimes allowed the magnet to shift, thus activating the radio transmitter. This caused a problem in attempting to find a lost whale in 1983 that had two floats attached to it (described above). When one float was located $120 \mathrm{~km}$ from the village with no evidence of a whale nearby, a search was initiated for the second float to determine if it was attached to the whale. A signal was received shortly thereafter, leading the plane back to the village, where a magnet had become dislodged on a float stowed in a beached whaling boat. Similar problems occurred on occasion when whaling boats were out, but these resulted in only temporary interference, because crews with dislodged magnets were notified by other crews via CB-radio to secure the magnet. The redesigned clip reduced this problem, but rough seas and other events that jostle the float excessively can shift the magnet enough to activate the transmitter. The problem, minor as it is, could be solved by attaching the magnet more firmly to the plate, but this would hinder its removal when the float is deployed, thus interfering with deployment or causing deployment with the magnet in place, neither of which is acceptable. It is important, therefore, that whalers check the magnet periodically to ensure its proper placement, and they have been willing to do this.

When equipping boats with whaling equipment, including positioning of the float, our design requires that the lanyard attached to the magnet be tied to the boat or to the tow rope so that the magnet is definitely removed when the float is deployed. Attention to this critical point is necessary during preparation for the hunt. This has not been a problem to date, although presumably one whale that was struck and retrieved did not have an activated radio transmitter because the magnet was not removed upon float deployment. Fortunately the whale was in visual range during the entire episode and this oversight was not serious.

In whatever technology is available, there is always the element of human failure to contend with. The excitement of striking a whale and the subsequent pursuit, if necessary, can lead to procedural oversight. Attaching the magnet to the boat or rope prior to the hunt has eliminated, for the most part, the prospect of failing to activate the transmitter at the time of the strike. Failure to do so has not caused the loss of a whale, nor do we anticipate that it will in the future.

Radio Receiver and Antenna: Both radio receivers performed very well under the environmental conditions experienced during the fall hunt. Kaktovik whalers return to their village each day, so that recharging of receivers with AC voltage is possible. Nuiqsut whalers, however, camp on one of the barrier islands just to the northeast of Prudhoe Bay for the duration of their whaling season, thus exposing the receivers to less optimal conditions. However, they have not experienced any problems. The greatest hazard to the receivers in both locations is exposure to salt spray during stowage and use. Some of the boats are completely open and have no cabin in which to stow the equipment. As a result 1 of the 15 receivers required extensive refurbishing in 1986, following three years of use during the fall subsistence hunts. This can be avoided at least during storage if the receivers are stowed in plastic bags or boxes that minimize exposure to spray. This degree of protection is not always possible in a boat that is in pursuit of a struck whale because the receiver is then in active use by one of the crew members. However, the minimal problems experienced thus far show that adequate protection is provided most of the time.

The receiving antenna selected has been very successful in maintaining contact with struck whales and finding lost ones, both from whaling boats and from aircraft. The relatively small size, the excellent directionality, and the disassembly feature for storage of the antenna are excellent features, and whaling crews have been pleased with its performance. 


\section{Range Tests}

The test conducted specifically to determine the range of detectability of the radio-instrumented floats in marine water was plagued with problems. The range of $32 \mathrm{~km}$ achieved near Barrow from an altitude of $2040 \mathrm{~m}$ was less than expected, but the engine ignition system of the Cessna 185 aircraft was exceptionally noisy and was felt to be the major factor preventing detection at greater range.

The $61 \mathrm{~km}$ range achieved from $1220 \mathrm{~m}$ altitude near Fairbanks was considerably better, but the test on freshwater was not felt to be directly applicable in simulating tracking a struck whale. It did, however, provide a better indication of the telemetry system's capability than did the test at Barrow.

The best range information came from several attempts to locate struck whales that had escaped whaling crews near Kaktovik in 1983, 1984, and 1986. One and two days after a whale was struck and lost near Kaktovik in 1983 a radio signal was detected. The float was located $37 \mathrm{~km}$ north of the village using a Cessna 207 aircraft with two $\mathrm{H}$-antennas attached to the wing strut and pointing to the side of the aircraft. On the fourth day after the strike a twin-engine Piper Navajo equipped with two $\mathrm{H}$-antennas, one mounted under each wing and also pointing to the side, detected the radio signal at about $40 \mathrm{~km}$ from an altitude of $2100 \mathrm{~m}$ while flying directly at the lost float. This range of detection was minimal because the sides of the directional antennas, and thus the orientation with the least gain, were pointed at the float. Had the antennas been pointed forward in parallel with the flight path, the range of reception would have been considerably greater, perhaps approaching $60 \mathrm{~km}$.

In 1984 an effort was made to locate a struck but lost whale near Kaktovik using the same twin-engine Piper Navajo described above. At $300 \mathrm{~m}$ altitude, as the plane left the Kaktovik airstrip, the radio signal was detected off the left wing at a distance of $48 \mathrm{~km}$ north.

In 1986, a struck but lost whale was located with a DeHavilland Twin-Otter aircraft equipped with $\mathrm{H}$-antennas, as previously described. A radio signal was detected as the aircraft left the Kaktovik airstrip (D.K. Ljungblad, pers. comm. 1987). The float and whale were located $48 \mathrm{~km}$ north.

These examples of detection range from aircraft and the fact that all radio-instrumented floats attached to whales were subsequently located, except the two described in the previous section, indicate that the radio-telemetry equipment used on this project has performed extremely well under the environmental conditions during August-October in northern Alaska.

\section{Fall Subsistence Hunts at Kaktovik and Nuiqsut}

During the fall bowhead whale subsistence hunts at Kaktovik in 1983 through 1988 and at Nuiqsut during 1986 and 1987 (heavy ice prevented any strikes in 1988), 12 whales were struck, of which 8 were retrieved (Table 2). Six whales (4 at Kaktovik, 2 at Nuiqsut) were killed immediately or were in visual range during the entire pursuit. Radio signals were not required to maintain contact with these whales, although the whaling crews at Kaktovik gained experience using the telemetry equipment in these cases. Two of the 8 whales were temporarily lost but subsequently found using the radio signal
TABLE 2. Bowhead whales struck during the fall subsistence hunts using radio-instrumented whaling floats: Kaktovik, 1983 through 1988; Nuiqsut, ${ }^{1} 1986$ and 1987, Alaska

\begin{tabular}{cl}
\hline \hline $\begin{array}{c}\text { Number of } \\
\text { whales struck }\end{array}$ & \multicolumn{1}{c}{ Explanation } \\
\hline 6 & $\begin{array}{c}\text { Whales retrieved; never out of view of whaling boats. } \\
\text { Whales lost but retrieved } 1 \text { and } 2 \text { days later using } \\
\text { radio signals to home in on them } 11 \text { and } 48 \mathrm{~km} \\
\text { respectively offshore. }\end{array}$ \\
$\begin{array}{c}\text { Whale lost. Harpoon pulled out of whale immediately } \\
\text { after strike. All equipment retrieved. } \\
\text { Whale lost but float found the following day using } \\
\text { radio signal to home in on it } 24 \text { km offshore. } \\
\text { Harpoon pulled out of whale. All equipment } \\
\text { retrieved. }\end{array}$ \\
$\begin{array}{l}\text { Whales lost but floats found } 120 \text { and } 48 \mathrm{~km} \text { offshore. } \\
\text { Equipment not retrieved; assumed that either } \\
\text { harpoons had pulled out of whales or, less likely, } \\
\text { that tow ropes snapped. }\end{array}$ \\
12 & Total struck. \\
\hline \hline
\end{tabular}

'Heavy ice cover prevented Nuiqsut whalers from using their three strikes during 1988.

to home in on them (Table 2), one in 1986 the other in 1988. Details of these recoveries follow.

The whale struck on 15 September 1986 (North Slope Borough I.D. No. 86KK2) at Kaktovik was lost but retrieved two days later because the radio signal from the float permitted an aircraft and whaling boats to home in on the dead whale. Due to its $48 \mathrm{~km}$ distance from the village, it is highly improbable that the whale would have been retrieved if searchers had relied only on visual detection of the whale and/or float. After the whale was struck, the whaling boats had to return to the village due to approaching darkness. The next morning the whaling boats again located the float by homing in on the radio signal; it had drifted $8-16 \mathrm{~km}$ to the west. Fog began to form in the area before the whale could be sighted, and the boats were forced again to return to the village. Later that day the radio signal was located from the air but fog prevented a visual search of the area (J.C. George, pers. comm. 1986). The following day the float with whale still attached was located from the air by homing in on the radio signal, and whaling boats were directed to the site. The dead whale was then towed to shore. This episode, in addition to having led to the retrieval of a lost whale, illustrates the ability to use the radio signal to locate a whale and float even when overcast or fog conditions prevented visual inspection of the sea surface. This can lead to more efficient search for and retrieval of a whale when light and/or water and ice conditions permit launching the whaling boats.

The whale struck on 23 September 1988 (I.D. No. 88KK1) at Kaktovik was lost but retrieved one day later using the radio signal from the float to guide the crews to the whale. It was located about $11 \mathrm{~km}$ from the village. It is highly doubtful that this whale would have been recovered if searchers had been dependent on only a visual search, because extensive ice floes provided a difficult patchwork in which to see a whale or even a brightly colored float. After the whale was struck, it swam into heavy ice, where pursuit with boats was virtually impossible. The float was dragged through and 
under ice floes, thereby being subjected to considerable stress. Whalers returned to the village due to ice and approaching darkness. The following morning a twin-engine aircraft with a receiving antenna inside the plane (not recommended because the radio signal is substantially attenuated by the metal fuselage, thus greatly decreasing range) located the whale using the radio signal. The signal was weak, but the aircraft gave the whale's position to the whaling boats and they were able to find the whale and retrieve it. The float had been damaged by the ice and was partly deflated and full of water, which could have contributed to the short range reported by the aircraft. A $5 \mathrm{~cm}$ tear occurred near the location where the radio transmitter was attached to the float. Although riding low in the water and partially filled with salt water, the float with its transmitter effectively guided the aircraft and boats to the whale, after which it was towed to the village.

Four (all from Kaktovik) of the 12 whales that were struck were subsequently lost, 2 because the harpoons had pulled free of the whales (Table 2). One came out immediately, the other within 24 hours of the strike. In the latter case, pursuit of the whale had to be terminated because of the encroaching darkness, but the radio signal permitted the boats to locate the float the following day $24 \mathrm{~km}$ offshore. It had been caught on an ice floe during the night and the resultant force pulled the harpoon free from the whale. All the equipment was retrieved.

The two other whales that were lost were never seen again, although both floats were located using the radio equipment (Table 2). They were determined by the whaling captains to be too far offshore $(120$ and $48 \mathrm{~km}$ ) to attempt retrieval given the water conditions and the fact that no whales could be observed in the vicinity of the floats. Although the float found $120 \mathrm{~km}$ from the village was on an ice floe, which could have hidden the whale, the other float was in open water, where a whale should have been visible if present. It is assumed in the latter case, and perhaps in both cases, that the harpoons had pulled out of the whales or, less likely, that the ropes had severed.

The net result of the eight fall subsistence hunts included in the course of this study, including six at Kaktovik and two at Nuiqsut, was eight whales landed and four lost, for a retrieval percentage of 67 . Had the radio-instrumented floats not been in use the retrieval percentage would have been 50 . If the harpoons had remained in the two whales that were struck and from which all the equipment was subsequently retrieved, it is quite possible that there would have been an $83 \%$ success. Those two floats found but not retrieved probably would have represented struck and lost whales, because the one that was $120 \mathrm{~km}$ from the village was too far to safely retrieve, and that found $48 \mathrm{~km}$ from shore in open water did not have a whale near it.

\section{CONCLUSIONS AND FUTURE PROSPECTS}

The use of radio telemetry to aid in the recovery of struck whales has been successful. The equipment selected and the design of the plates to attach the radio transmitter to the float have met or exceeded expectations. All floats but two that were attached to whales were either retrieved or relocated. Although only 2 whales of a total of 12 struck were retrieved because the radio signal from the instrumented floats al- lowed searchers to locate them, the retrieval rate increased to $67 \%$, up from $50 \%$ had these whales not been found and retrieved.

Having radio-instrumented floats attached to the 4 whales lost during the course of this project provided insight into another problem that leads to the loss of struck whales. The marking of a whale at the time of a strike entails attachment of a harpoon to which a rope and float are fastened. Should a whale flee, other than direct observation, the float is the principal means of maintaining contact with or finding a lost whale, so it is imperative that all three components function properly. The harpoon must stay in the whale, the rope must be able to withstand the forces applied by a swimming whale pulling a float through the water, and the float must remain attached to the rope. Failure of any one significantly increases the probability of losing a struck whale unless it dies within minutes of the strike. In only one known case during this project did an instrumented float come off the tow rope, and this was a float that was hurriedly tied to a line already fastened to a whale and to which an instrumented float was attached. When the rope and both floats were pulled through and under heavy ice, only the original float survived; the other apparently was sheared off and lost under an ice floe.

The ropes employed range from sisal to nylon climbing rope and have a high tensile strength. In no case during this project to our knowledge did a rope break. When ice is present, especially during the spring hunt, there is ample opportunity for the ropes to become abraded and break, but this is an infrequent occurrence. What occurs most often, and has been known to occur twice and perhaps four times during this project, is the tearing out of the harpoon when forces applied by the resistance of ice and water on the rope and float as they are being towed by a swimming whale exceed the holding capacity of the harpoon head. It is noteworthy to mention here that the AEWC is currently providing whalers with harpoons that hold better than some in use now. This should reduce the number of struck and lost whales during both the spring and fall hunts.

The success of the radio-telemetry program over the first four years prompted the AEWC (1987) to pass a resolution to expand the use of this technology to other villages where water and ice conditions are suitable for its use. As a result, ten sets of radio-telemetry equipment (radio frequency of $148.751 \mathrm{mHz}$ ) were provided to the AEWC for use by the fall whaling crews (fewer than the 39 total crews registered) at Barrow, although they also would be suitable for use in spring if a wide and relatively ice-free lead is present. In addition, the whaling villages of Gambell and Savoonga on St. Lawrence Island have expressed a desire to be so equipped for their spring hunt, which is often characterized by relatively open water.

Three whales (I.D. Nos. 88B9, 88B10, and 88B11) were struck and landed at Barrow during fall 1988 by whaling crews not equipped with radio-instrumented floats. The whales never escaped and, therefore, radio telemetry would not have aided their recovery. These whales were not included in the calculation of struck and retrieved percentages reported above because radio-instrumented floats were not used by these crews. Including these three whales in the calculation, the percent retrieved for fall hunts during 1983-88 is 73 (11 of 15 struck). 
Due to the limitations of radio transmitters in marine waters where their submersion prevents tracking, the AEWC is supporting a development project to research the possibility of using underwater acoustic "pingers" to help in the recovery of struck whales. These, if found to be successful in preliminary tests, could be used by whaling crews that hunt in the spring where extensive ice provides a readily available hiding place for struck whales. The pingers would permit their location and thus possible retrieval.

It is clear that the AEWC is making significant efforts to reduce the number of struck and lost whales. They are presently supporting at least four projects whose goals are the recovery of all bowhead whales struck during the annual subsistence hunts. These are the radio-instrumented float and underwater acoustic "pinger" programs, the improved harpoon design, and the development of a more effective bomb. With these new technologies complementing traditional whaling techniques, it is very likely that the struck and lost rate will be significantly decreased.

Of course, there is a cost associated with these technological advancements. Some of these are most costly during the research and development phase and during initial equipment provision, as, for example, the float instrumentation program described here. But now that the float program has become operational, it is a matter of maintaining existing equipment (receivers/antennas), whose initial cost is about $\$ 800$, and replacing instrumented floats, should any become lost, at a cost of about $\$ 850$. Given the battery life of 8-10 years, the availability of radio-instrumented floats over this time span to aid in the recovery of struck whales allows amortizing this cost over a long period. Following battery replacement, these units will again be available for 8-10 years. One float provided to a whaling captain (N. Solomon) in Kaktovik in 1983 has been attached to four whales, two of which (I.D. No. 86KK2 and 88KK1) would have been lost had a radio transmitter not been attached to the float. We consider this more than an ample return for the cost of the instrumented float and the receiving equipment, which should have an indefinite life span with only minimal maintenance. Even extending the cost of equipment replacement to all ten whaling crews at Kaktovik, estimated at about $\$ 20000$, the retrieval of two whales certainly justifies this cost. We feel strongly that this instrumentation will continue to be effective in assisting successful whaling crews in retrieving struck whales, and it is a concrete demonstration that the AEWC is making good on their commitment to reduce the numbers of struck and lost whales.

Given that the subsistence harvest of bowhead whales by Eskimos will continue into the foreseeable future, we believe that the cost of development and/or application of new technology to improve the recovery rate of struck whales is reasonable. But some developments, such as the float instrumentation program described here, should not be implemented in all villages. Instead each village should be provided with the technology that will most benefit its whaling activities. For example, a fall whaling village such as Kaktovik is best suited to the use of radio-instrumented floats because relatively open water is the norm, but a spring whaling village such as Pt. Hope would not be suited to the use of these floats because of the extensive ice cover that characterizes its season of whaling. In contrast, a more effective bomb should be provided to all villages. Thus, judicious distribution and use of new technologies to aid in the recovery of struck whales will justify their costs in the long run, if they have not already.

\section{ACKNOWLEDGEMENTS}

This project was funded by the Alaska Eskimo Whaling Commission and the North Slope Borough. We are particularly grateful to the whaling captains and crews at Kaktovik and Nuiqsut who were willing and enthusiastic about testing the instrumented floats. The efforts and cooperation of the Kaktovik whalers were instrumental in achieving our objectives, and their comments following the completion of the 1983 fall hunt were invaluable in evaluating and finalizing the float design. Numerous individuals provided assistance in many ways, but we particularly thank $\mathrm{N}$. Solomon, of Kaktovik; T.F. Albert, J.C. George, B.P. Nageak, and R.H. Nalikak, of the North Slope Borough Department of Wildlife Management; D.K. Ljungblad, of Naval Ocean Systems Command in San Diego; S.M. Tomkiewicz, Jr., of Telonics; H.C. Stanley; and W. Audi and his staff of Audi Air in Kaktovik and Prudhoe Bay. We also thank D.A. Borchert for preparing the figures, A. Jones and D. Cochran for typing the manuscript, and T.F. Albert, A.P. Snow and two anonymous reviewers for comments on earlier drafts of this manuscript. A portion of this paper was presented to the International Whaling Commission Scientific Committee as Report No. SC/40/PS9 in 1988.

\section{REFERENCES}

ALASKA ESKIMO WHALING COMMISSION. 1987. Resolution 87-07: A resolution for the use of radio instrumented floats for the recovery of struck and lost bowhead whales. Alaska Eskimo Whaling Commission, Barrow, Alaska. 1 p.

DRONENBURG, R.B., CARROLL, G.M., RUGH, D.J., and MARQUETTE, W.M. 1983. Report of the 1982 spring bowhead whale census and harvest monitoring including 1981 fall harvest results. Reports of the International Whaling Commission 33:525-537.

FOLLMANN, E.H. 1986. Instrumentation of subsistence whaling equipment with electronic devices to aid in the recovery of struck but lost bowhead whales. Final Report for the Period July 1, 1985, through June 30, 1986, to the North Slope Borough, Barrow, Alaska. Contract No. 85-64. 20 p. 1987. Instrumentation of subsistence whaling equipment with electronic devices to aid in the recovery of struck but lost bowhead whales. Final Report for the Period July 1, 1986, through June 30, 1987, to the North Slope Borough, Barrow, Alaska. Contract No. 86-64. 53 p. and MANNING, A.E. 1984. Instrumentation of whale harpoon floats with radio-transmitters. Final Report for the Period March 1, 1983, through June 30, 1984, to the North Slope Borough, Barrow, Alaska. Contract No. 83-36. 38 p.

1985. Instrumentation of subsistence whaling equipment with electronic devices to aid in the recovery of struck but lost bowhead whales. Final Report for the Period July 1, 1984, through June 30, 1985, to the North Slope Borough, Barrow, Alaska. Contract No. 84-92. 39 p.

GEORGE, J.C. 1981. Current procedure for allocating the bowhead whale, Balaena mysticetus, by the Eskimo whalers of Barrow, Alaska. In: Albert, T.F., ed. Tissue Structural Studies and Other Investigations on the Biology of Endangered Whales in the Beaufort Sea. Report to the Bureau of Land Management from the Department of Veterinary Science, University of Maryland, College Park, Maryland. 789-803.

INTERNATIONAL WHALING COMMISSION. 1978. Report of the scientific committee. Reports of the International Whaling Commission 28:38-92.

1982. Aboriginal/Subsistence Whaling (With Special Reference to the Alaska and Greenland Fisheries). Reports of the International Whaling Commission, Special Issue 4. $86 \mathrm{p}$.

MARQUETTE, W.M., and BOCKSTOCE, J.R. 1980. Historical shore-based catch of bowhead whales in the Bering, Chukchi, and Beaufort Seas. Marine Fisheries Review 42:5-19.

MITCHELL, E.D., and REEVES, R.R. 1980. The Alaska bowhead problem: a commentary. Arctic 33:686-723. 
and EVELY, A. 1986. Bibliography of Whale Killing Techniques. Reports of the International Whaling Commission, Special Issue 7. $161 \mathrm{p}$.

MURPHY, E.C., and JARRELL, G.H. 1983. Simulation studies of population trends in western arctic bowhead whales. Reports of the International Whaling Commission 33:509-523.
RAINEY, F. 1940. Eskimo method of capturing bowhead whales. Journal of Mammalogy 21:362.

ZEH, J.E., and RAFTERY, A.E. In press. 1986 and combined bowhead population estimates. Appendix 3 to the Report of Sub-Committee on Protected Species and Aboriginal Subsistence Whaling. 1988 Meeting of the Scientific Committee of the International Whaling Commission, San Diego, California. 